Рибальченко Гавриїл Олександрович доктор теології, доктор філософії, доцент кафедри теології та християнської комунікації, Міжрегіональна Академія Управління персоналом, вул. Фрометівська, 2, м. Київ, 03039, тел.: (067) 232-1688, e-mail: gavriyl@ukr.net, https://orcid.org/ 0000-0002-9152-5763

\title{
ЕСХАТОЛОГІЧНІ ТА РЕЛІГІЙНО-ФІЛОСОФСЬКІ ПОГЛЯДИ С. Л. ФРАНКА
}

Анотація. Стаття присвячена аналізу есхатологічної проблематики видатного російського релігійного мислителя С. Л. Франка. У своїх дослідженнях філософ звертався до питань релігії, моралі, політики, мистецтва і літератури. Соціальні ідеї релігійного мислителя знаходять дивну притягальну силу в сфері вивчення духовних і соціальних основ сучасного суспільства. Осмислення культурної, історичної та соціальної реальності найяскравіших представників релігійної філософської думки ХХ століття стає предметом сучасної церковної та світської науки.

С. Л. Франк розглядає вчення про Бога, Церкву, світ, історію та місію людини, а також детально аналізує можливості та потенціал православного богослужіння (практики) та християнського богослов'я (теорії). Він вправно показує, що в богословському, філософському та публіцистичному спадку визначних християнських богословів есхатологія відіграє провідну роль. Есхатологічна думка Православної Церкви не тільки розкриває сенс Євхаристії, церковних таїнств, богослужіння, але й дає християнську оцінку історичних подій, культурної та суспільно-політичної діяльності всього людства в перспективі вічності.

Есхатологія виступає непохитним пунктом віри, надії, місії та глобальної перспективи майбутнього християнства. Вона задає вектори духовної орієнтації не лише для християнина, але й для всього суспільства. Проте слід звернути увагу на ту обставину, що С. Л. Франк цілком критично ставився до реального стану есхатологічної проблематики.

Вчення С. Л. Франка про Царство Боже логічно випливає з учення про Бога та сенс людського життя. Царство Боже напрямки пов'язане 3 християнською активністю та внесенням християнством у світ любові и світла Правди Божої. Прагнення до Царства Божого, покладання на силу й владу Бога, чекання на друге й славне Пришестя Христове не звільняє християн від «політики любові», духовного творення та суспільного вдосконалення в земній історії.

Філософське розуміння соціальної діяльності християнства С. Л. Франк вбачав у духовному та соціальному преображенні життя суспільства. Християнське життя за своєю сутністю є невтомним творенням добра, боротьба зі 
злом, постійне творення, динаміка, проектування світла Божого на площину земного буття. Історія людства $\epsilon$ боголюдським процесом. Людина духовно зміцнюється й духовно самовдосконалюється тільки шляхом утвердження добра та подолання зла, що, в свою чергу, і є основою духовного розвитку суспільства.

Ключові слова: релігійна філософія, есхатологія, філософія історії, релігійна етика, культура, духовні цінності, політика, духовний досвід.

Rybalchenko Gavriil Oleksandrovych Doctor of Theology, Doctor of Philosophy, Associate Professor of Theology and Christian Communication, Interregional Academy of Personnel Management, Frometivska St., 2, Kyiv, 03039, tel.: (067) 232-16-88, e-mail: gavriyl@ukr.net, https://orcid.org/0000-0002-9152-5763

\section{ESCHATOLOGICAL AND RELIGIOUS-PHILOSOPHICAL VIEWS OF S.L. FRANKO}

Abstract. The article is devoted to the analysis of eschatological problems of the outstanding Russian religious thinker S.L. Frank. In his research, the philosopher addressed issues of religion, morality, politics, art and literature. The social ideas of the religious thinker find a strange appeal in the study of the spiritual and social foundations of modern society. Understanding the cultural, historical and social reality of the brightest representatives of religious philosophical thought of the XX century is becoming the subject of modern church and secular science.

S.L. Frank examines the doctrine of God, the Church, the world, the history and mission of man, and analyzes in detail the possibilities and potential of Orthodox worship (practice) and Christian theology (theory). He skillfully shows that eschatology plays a leading role in the theological, philosophical and journalistic heritage of prominent Christian theologians. The eschatological thought of the Orthodox Church not only reveals the meaning of the Eucharist, church sacraments, worship, but also gives a Christian assessment of historical events, cultural and socio-political activities of all mankind in the perspective of eternity.

Eschatology is an unshakable point of faith, hope, mission and the global perspective of future Christianity. It sets the vectors of spiritual orientation not only for the Christian, but for society as a whole. However, we should pay attention to the fact that SL Frank was quite critical of the real state of eschatological issues.

S.L. Frank's teaching about the Kingdom of God logically follows from the teaching about God and the meaning of human life. The kingdom of God is connected with Christian activity and the introduction of Christianity into the world of love and the light of God's Truth. The desire for the Kingdom of God, the reliance on the power and authority of God, the anticipation of the second and glorious Coming of Christ do not free Christians from the "politics of love," spiritual creation, and social improvement in earthly history.

S.L. Frank saw a philosophical understanding of the social activities of Christianity in the spiritual and social transformation of society. The Christian life in its 
essence is a tireless creation of good, the struggle against evil, constant creation, dynamics, projecting the light of God on the plane of earthly existence. The history of mankind is a divine-human process. Man is spiritually strengthened and spiritually selfimproved only by establishing good and overcoming evil, which, in turn, is the basis of the spiritual development of society.

Keywords: religious philosophy, eschatology, philosophy of history, religious ethics, culture, spiritual values, politics, spiritual experience.

Постановка проблеми. Стрімкі зрушення в людському житті, особливо за доби пандемії та соціальної роз'єднаності актуалізують як ніколи питання про сутність і сенс людського буття. Історичні, політичні, економічні та культурні вектори російської релігійної філософії набувають украй важливого значення для сучасної філософії, педагогіки та релігієзнавства. В умовах нових глобальних викликів цивілізації особливої актуальності набуває християнське вчення про останні часи, сенс, мету й розвиток людської історії - есхатологія. Науковці зазначають, що есхатологічна проблематика - це не лише біблійне пророцтво про майбутнє всього людства (футурологічна концепція), але й розумне, осмислене історичне конструювання земної реальності християнського світу в світлі вчення про Царство Боже [1; 2; 3].

Зазначимо, що есхатологічні ідеї російського релігійного мислителя й філософа Семена Людвіговича Франка (1877 - 1950) сформувалися у пошуку релігійних та духовно-моральних відповідей на виклики сучасного йому світу. Релігійний філософ активно займався популяризацією християнського віровчення, облаштуванням життя суспільства в світлі християнських цінностей. На наш погляд, він зробив вагомий внесок у розвиток не лише загальних європейських філософських гуманістичних ідей XX століття, але й у становлення есхатологічної думки Православної Церкви як науки. Особливо значущою ця роль була в осмисленні політики, творчості, науки та культури в парадигмі релігії та духовних спрямувань людини.

Відомо, що будь-яка релігійно-богословська думка містить у собі есхатологічні імпульси, оскільки, вона звернена до світу майбутнього, філософії історії, прогностики й осмислення теперішнього через призму прийдешнього Царства Божого. На наш погляд, виникнення цікавості до питань кінця людської історії пояснюється не лише впливом футурологічних прогнозів майбутнього, але також і тією складною, суперечливою геополітичною ситуацією, яка склалася в сучасному світі [3].

Аналіз останніх досліджень і публікацій. Останнім часом у світ вийшло чимало монографій, статей, книг, пов'язаних із проблематикою есхатологічної думки християнства. Величезний внесок у розвиток християнської есхатології в іiі теоретичному аспекті зробили відомі релігійні мислителі: Володимир Соловйов, Микола Федоров, Лев Тихомиров, Лев Карсавін, Микола Бердяєв, протоієрей Сергій Булгаков.

На сьогоднішній день есхатологічною проблематикою займаються відомі 
православні богослови: митрополит Георгій (Ходр), митрополит Іоанн (Зізіулас), митрополит Калліст (Уер), митрополит Іларіон (Алфєєв), протоієрей Діонісій Мартишин, протоієрей Володимир Кашлюк, священник Павло Бочков, професор О. І. Осипов, С. М. Бортник [1 - 7].

Дослідницьке проблемне поле есхатології пов'язане 3 іменами відомих католицьких та протестантських богословів: Юргена Мольтмана, Ніколаса Томаса Райта [10], Томаша Шпидлика, Ганса Кюнга, Девіда Бентлі Харта, Христоса Яннараса, Карла Християна Фельми.

Переходячи до творчості С. Л. Франка [8-9], зазначимо, що в багатьох своїх філософських книгах та богословських роздумах він виразно й правдиво зачіпав питання буття Бога, сутності релігійної віри, сенсу людського життя. Без віри в Бога, вважав С. Л. Франк, не існує повноцінного, насиченого та радісного життя людини, безглуздим $\epsilon$ існування релігійних обрядів, законів, правил та заборон.

Мета статті - виявити суттєві риси християнської есхатології в релігійнофілософському спадку С. Л. Франка. У зв’язку з цим визначимо наступні головні пізнавальні завдання: науці;

— виявити та проаналізувати предмет християнської есхатології в сучасній

- за допомогою детального аналізу християнської есхатології розглянути головні аспекти християнської філософії історії, осмислити питання взаємовідносин християнства та культури, ролі людини, народу в історії.

Виклад основного матеріалу. С. Л. Франк, спростовуючи облудні уявлення атеїстів про Творця, заперечуючи схоластичну «академічну» перевагу книжкової літери над живим релігійним досвідом, стверджує, що Бог є вищим над усякі раціональні поняття, філософські визначення. Він перевищує будь-яку думку. «Бог $\epsilon$ взагалі цілком інакше, ніж усе інше, що ми знаємо....Тільки-но я намагаюся охопити Бога думкою, виразити Його сутність у будь-якому понятті, Він уже вислизає від мене» $[8$, с. 501].

Для того щоб на рівні богословських та філософських визначень виразити релігійний досвід пізнання Бога, необхідні не слова і формулювання, твердить Франк, а «радше «вигуки», ніж думки, радше почуття, ніж поняття» [8, с. 502]. Філософ, роздумуючи над вірою в особистого Бога, зазначає, що богослову радше слід говорити не про існування Бога, а про реальність Його живої Присутності. Людина, на думку філософа, в житті Бога має вбачати джерело свого власного буття.

Для С. Л. Франка віра в Бога нерозривно пов'язана 3 есхатологічною проблематикою. «Христос приніс звістку про Бога як люблячого Отця; але водночас і ніби неподільно з цим Він приніс і «добру звістку» про Царство Боже. Його Євангеліє - що, як відомо, і значить «добра звістка» - позначається як Євангеліє царства»»»[8, с. 503].

Зазначимо, що вихідним пунктом есхатології С. Л. Франка $є$ ідея Царства Божого. За вченням філософа, не можна говорити про справжню любов до Бога, про віру в Творця, якщо людина не шукає Царства Божого. Філософ розлого 
розмірковує: «Царство Боже $є$ в цьому сенсі вічним надбанням та вічною батьківщиною людської душі, воно $є$ нічим іншим, як буттям, наскрізь пронизаним и просвітленим божественними силами, - буттям, у якому Бог $\epsilon$ «все в усім», царством істини, добра, краси, святості. «Царство Боже» в цьому сенсі настільки нерозривно пов'язане з Богом, що одне є невіддільним від іншого. Царство Боже є ніби сферою буття, осяяною та пронизаною світлом Божим, якимсь ореолом світла, що виходить від Бога, Його оточує і в цьому сенсі до нього співналежить. Жодна віра в Бога не допоможе людині, якщо вона від самого початку не мислить Бога осередком та джерелом «Царства Божого» якщо вона не шукає цього царства, не усвідомлює себе дотичною до нього, не відає, що володіє цим «скарбом на небесах», має цю батьківщину» [8, с. $503-504]$.

Віруючий християнин, за С. Л. Франком, це людина, яка не лише молиться у храмі та волає до Бога в келійних молитвах, але, насамперед, яка виконує волю Бога, живе за Правдою Божою. Іншими словами, християнин, який не має живої та дієвої любові «до ближнього, зовсім не знає Бога, не вірить у Нього» [8, с. 504].

Отже, християнська філософія історії, так само як і есхатологічна думка Православної Церкви, мають глибокі історичні корені та розвиваються як форма церковної, суспільної свідомості на основі Святого Письма та Священного Передання Церкви, 3 урахуванням наукових досягнень історичної науки та філософії [1, с. 5 - 7]. Виходячи з есхатологічного вчення Християнської Церкви, наслідуючи Бога в любові й творенні добра, успадковуючи життя Христа, християнин, на думку С. Л. Франка, мусить бути творцем, носієм добра, випромінювати світло, тепло, тим самим оживотворювати весь життєвий простір. Франк писав: «Справа не в тому, чи «визнає» людина існування Бога чи ні, а в тому, чи має їі душа дотик до скарбів «Царства Божого», до дарів святого Духа, чи проникає в іiі душу світло, чи осяяна й зігріта вона цим світлом божественної любові» [8, с. 505].

Мислитель вважає, що «істинною метою людського життя, до якої хоче вести людей християнство, є самоздійснення, розквіт людської душі через таке їі самообмеження та самоподолання, яке засноване на всеохопній любові до людей та до всього буття» [8, с. 622 - 623]. Богослов'я, антропологія та філософія С. Л. Франка об'єднані однією думкою про те, що християнин, прилучаючись до Христа, позбавляється своєї «нікчемності як безсильної створеної істоти й набуває влади стати «дитиною Божою» (Ін. 1:12)». Людство, на думку Франка, покликане «обожитися» - прилучитися до Бога та проникнутися Богом — як єдиною справжньою, найглибшою основою своєї істоти. Людина на шляху до Бога має зректися своєї гріховної ізоляції, перенести центр або опорний пункт свого буття зі своєї чисто природної істоти на Бога . Тільки осягаючи Бога, прилучаючись до Нього, людина здобуває саму себе, розкриває свій справжній світ, здобуває цілісне життя й справжню реальність буття. Таким є головне послання богословської думки С. Л. Франка. 
Людство, вільно підкоряючись волі Творця, набуває повноти власного існування на землі. У філософії Франка вчення про Бога й спасіння людини щільно переплетені 3 ідеєю всеєдності, соборності всього людства. Для С. Л. Франка принциповим виявляється момент усвідомлення людиною своєї співпричетності до суспільної єдності. Філософ вважає, що святість, духовність, милосердя та аскетизм розкриваються через виявлення любові до ближнього та соборність усього людського роду. На нашу думку, християнство $є$ релігією справжньої людяності.

Вчення про Бога та людину в філософії С. Л. Франка є немислимим без любові та діяльного преображення світу. 3 віри в Бога, навчає філософ, має випромінюватися «дієва любов до ближнього, благословення всього сущого, самовіддане служіння〉 [8, с. 627]. Без творчості, любові, душевної відкритості, любовної спрямованості, жертовного служіння ближньому - немає достеменної любові до Бога та справжнього духовного шляху осягнення Творця.

Головною ідеєю Франка $є$ розуміння того, що лише самовіддана любов $\epsilon$ «тверезо-розумовим» - «єдиним, правильним та плідним шляхом боротьби зі злом та перемоги над злом» [8, с. 629]. Виходячи 3 того, що зло є шляхом роз'єднаності, ворожнечі та ненависті. Філософ навчає, що перемогти зло можна лише найсильнішою, найчистішою любов’ю та самовідданням. «Іншого способу сутнісного, реального подолання та знищення зла взагалі не існує» [8, с. 629].

Таким чином, вчення про Царство Боже у філософії С. Л. Франка осмислюється в парадигмі вчення про Бога, людину та суспільство. Царство Боже, на думку Франка — це не схоластичні ідеї про «загробне життя», а «не що інше, як утвердженість людського буття в реальності Бога та Його правди» [9, с. 78]. «Царство Боже» в цьому сенсі $\epsilon$ вічним надбанням людини» $[9$, с. 78$]$.

С. Л. Франк навчає, що єдиною спільною метою та цінністю християнського життя $\epsilon$ «царство Боже й правда Його». Відповідно наблизитися до Царства Христового можна лише шляхом пошуку «спасіння», «відкуплення», «обоження» світу, тобто його преображення в «царство Боже» [9, с. 180]. Саме у здійсненні цього завдання Франк вбачав священну місію християнина в світі. Цю думку добре охарактеризував визначний західний богослов, єпископ Даремський Том Райт: «Царство приходить тоді, коли Церква, силою Духа йде в цей світ» $[10$, с. $150-151]$.

Християни, наполягає філософ, у міру своїх сил мають уподібнюватися до свого Небесного Отця, Який не лише рятує створений Ним світ, але й охороняє, підтримує його буття [9, с. 180]. Закликаючи християнина до преображення світу й обоження, Франк уникав крайнього утопізму та хіліазму, притаманного багатьом філософам, революціонерам та реформаторам. Повнота «Царства Божого», як повнота Божественної Правди, згідно до філософії С. Л. Франка, є здійсненною лише через кінець світу, через його преображення в нову, вищу, досконалу форму буття тільки силою Божою. Франк пише, що «прагнення зовнішніми, людськими організаційними засобами встановити царство Боже на 
землі не лише виявляється фактично нездійсненним, але неминуче призводить до прямо протилежного підсумку - до розгнуздання й тріумфу сил зла, до якогось царства пекла на землі» [9, с. 185]. Вся історія людства є яскравим підтвердженням цих слів.

На думку філософа, «всі людські «рятівники світу», первинно натхненні високими, шляхетними почуттями співчуття до лих людей та прагненням утвердити справедливий порядок, царство добра й правди — всі вони в силу якогось фатального діалектичного процесу перетворювалися на кровожерних тиранів, насильників, катів» [9, с. 185]. Тим самим виникала, на думку С. Л. Франка, «єресь утопізму».

Боротьба людства за світле майбутнє, яке тримається на фундаменті безбожності, атеїзму, невірства, завжди закінчується кров'ю, насильством, поневоленням, рабством та приниженням людини. Замість рівності, братерства й справедливого суспільства утопісти, революціонери, реформатори, відкидаючи Бога, приносять людині деспотизм, тиранію, панування зла й ненависті на землі. Вихід з утопічного мислення людства Франк вбачає в християнському реалізмі, принципова відмінність якого від утопізму полягає в тому, що християнин усвідомлює наявність зла в світі, але вільно вдосконалює життя через внутрішнє моральне просвітлення. «Це вдосконалення полягає в максимальному розвитку й напруженні основоположної християнської енергії — любові» [9, с. 199].

Християнський реалізм, згідно з мислителем, здатний реально розширити обрій суспільного мислення й самого життя суспільства. $С$ закони, правила, дисципліна, суспільна мораль, домовленості, але вони лише тимчасово підтримують примусовий соціальний порядок. Натомість християнська мораль, благодать і свобода в Бозі є Його шляхом «дієвої, цілющої та рятівної сили любові» [9, с. 199], яка забезпечує соціальний та духовний розвиток суспільства у відповідальності перед Творцем.

С. Л. Франк навчав, що світ «увесь лежить у злі», тобто в темряві, але він потребує, аби християни, не втікаючи від світу, не ізолюючись від соціальних явищ, вносили в нього світло Боже, енергію любові. Головна мета християнського життя, на думку філософа, полягає в шуканні «Царства Божого й Правди Його». Людина, наслідуючи Творця в досконалості, здійснює свою священну місію в двох напрямах: «у формі прямої, безпосередньої скерованості волі на «Царство Боже» - і у формі побожної любові до образу Божого на землі — до святині людини» [9, с. 203 - 204].

С. Л. Франк зазначає, що Церква, будучи носієм святині Христової Правди, транслює в світ любов Божу. «Ця любов є, Звичайно, скорботною любов’ю, сповненою свідомості недосконалості об'єкта любові, — щось подібне до любові до хворої (фізично й морально) дитини, слабкість якої ми усвідомлюємо одночасно 3 усвідомленням добрих сил, потенційно прихованих в основі іiі особистості» [9, с. 204].

С. Л. Франк підкреслює, що в цьому полягає принципова відмінність християнської соціальної думки від єретичних принципів та ідей, для яких світ, 
творіння, соціальні феномени $є$ виявленням самого тільки зла. Християнська Церква визнає реальність боротьби між «світлом» і «темрявою», але ця боротьба сповнена євангельського оптимізму та духовної радості. Християнству є чужим похмурий, скорботний, дуалістичний світогляд, який зневажає та ненавидить світ як чисте втілення «темряви» [9, с. $204-205]$.

С. Л. Франк пояснює, що якщо Бог «так полюбив світ, що дав Сина Свого Однонародженого», i якщо найвищим завітом нашого життя $є$ прагнення до досконалості Отця нашого небесного, то ясно, що ми і в цьому стосунку маємо наслідувати його зразок і любити світ» [9, с. 205]. На думку філософа, зречення християнина від світу як сфери темряви має сполучатися 3 боротьбою людини проти зла, гріха й ненависті. Тільки любов'ю до священного первинно створеного світу та до самої людини як вінця творіння, можна преобразити й змінити світ.

Свобода, демократія, рівність, справедливість, до яких одвічно спрямоване людство, пояснює С. Л. Франк, немислимі без християнської любові та моралі. «3 любові до творіння та його вершині та найвищого вираження - людини, - 3 поваги до людини, як створеного носія божественного світла, випливає, як один 3 головних завітів християнської свідомості, пошана до свободи» [9, с. 206]. Філософ пише: «Забуття цієї істини є найбільшим гріхом, у який протягом багатьох століть впало історичне християнство, джерелом його слабкості та всієї опозиції проти нього. Бо пошана до вільної внутрішньої істоти людини $\epsilon$ необхідним вираженням істинної любові до людини - цього центрального християнського завіту» [9, с. 207].

Есхатологія С. Л. Франка є тріумфом богословських істин у сфері раціональної аргументації та християнської апологетики, перемогою над фальшивими, єретичними поглядами, які час від часу з'являються в історії християнства. Мислитель переконливо показує, що вчення про Бога, Царство Боже гармонійно сполучається $з$ християнським служінням світу й людині. Сенс людського життя, за Франком, полягає в тому, щоб творити добро та усіма силами зменшувати зло. Франк підкреслює, що християнська догматика, соціальна практика, мораль формулюють одну тезу: християнство, як релігія Боговтілення, проповідує про єдність людини й світу у Бозі, говорить про «іманентну присутність божественних сил, енергії Божественної істоти в самому творінні» [9, с. 207].

Слова про Боголюдськість і Боговтілення дають міцну основу для віри в верховенство абсолютної Правди Божої, Царства Божого та соціального служіння Церкви, толерантного, любовного ставлення до святині людського та світового буття, хоча й затьмареного та викривленого силами гріха. Релігійно-етична концепція Франка, заснована на християнському богослов”, $є$ однаково протилежною і світській філософській думці, байдужій до релігійних проблем буття, і несамовитому межовому аскетизму, в якому ідеї про спасіння гріховного світу вироджуються в ненависть і зневагу до самого світу, людини та світобудови в цілому.

Висновки. Таким чином, підводячи підсумок, необхідно зазначити. 
С. Л. Франк розглядає вчення про Бога, Церкву, світ, історію та місію людини, а також детально аналізує можливості та потенціал православного богослужіння (практики) та християнського богослов'я (теорії). Він вправно показує, що в богословському, філософському та публіцистичному спадку визначних християнських богословів есхатологія відіграє провідну роль. Есхатологічна думка Православної Церкви не тільки розкриває сенс Євхаристії, церковних таїнств, богослужіння, але й дає християнську оцінку історичних подій, культурної та суспільно-політичної діяльності всього людства в перспективі вічності.

Есхатологія виступає непохитним пунктом віри, надії, місії та глобальної перспективи майбутнього християнства. Вона задає вектори духовної орієнтації не лише для християнина, але й для всього суспільства. Проте слід звернути увагу на ту обставину, що С. Л. Франк цілком критично ставився до реального стану есхатологічної проблематики.

Вчення С. Л. Франка про Царство Боже логічно випливає з учення про Бога та сенс людського життя. Царство Боже напрямки пов'язане з християнською активністю та внесенням християнством у світ любові и світла Правди Божої. Прагнення до Царства Божого, покладання на силу й владу Бога, чекання на друге й славне Пришестя Христове не звільняє християн від «політики любові», духовного творення та суспільного вдосконалення в земній історії.

Філософське розуміння соціальної діяльності християнства С. Л. Франк вбачав у духовному та соціальному преображенні життя суспільства. Християнське життя за своєю сутністю $є$ невтомним творенням добра, боротьба зі злом, постійне творення, динаміка, проектування світла Божого на площину земного буття. Історія людства $є$ боголюдським процесом. Людина духовно зміцнюється й духовно самовдосконалюється тільки шляхом утвердження добра та подолання зла, що, в свою чергу, і $є$ основою духовного розвитку суспільства.

\section{Лimepamypa:}

1. Мартышин Д. С. Основы христианской эсхатологии: учеб. пособие. - К.: Издательство Лира-К, 2015. - 124 с.

2. Мартышин Д. С. Социально-философский анализ христианской эсхатологии в диалоге государственного управления и теологии // Аспекти публічного управління. 2019. - Т. 7. № 1-2. - С. 61-69.

3. Бочков П. В., Мартышин Д. С. Христианская эсхатология и социальная практика

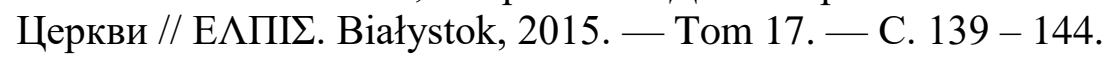

4. Ходр Георгий, митрополит Гор Ливанских. Призыв Духа: Церковь и общество / Пер. с. фр. — К.: Дух і Літера, 2006. — 284 с.

5. Иларион (Алфеев), митрополит. Конец времен: Православное учение / Митрополит Иларион (Алфеев). - М.: ЭКСМО, 2014. - 224 с.

6. Иоанн (Зизиулас), митрополит. Бытие как общение: Очерки о личности и Церкви / Предисл. протопресвитера Иоанна Мейендорфа; пер. с англ. Д. М. Гзгзяна. - М.: СвятоФиларетовский православно-христианский институт, 2006. - 280 с.

7. Кашлюк В. С. Христианская эсхатология в трудах представителей русской религиознофилософской мысли XX века: монография / Владимир Сергеевич Кашлюк. - К.: Лира-К, 2015. $-208 \mathrm{c}$. 
8. Франк С. Л. С нами Бог. - М.: АСТ, 2003. - 750 с.

9. Франк С. Л. Свет во тьме. Опыт христианской этики и социальной философии. - М.: Факториал, 1998. - 256 с.

10. Райт Т. Главная тайна Библии: Смерть и жизнь после смерти в христианстве / Том Райт; [пер. с англ. М. И. Завалова]. — М.: Эксмо, 2009. — 384 с.

\section{References:}

1. Martyshin, D. S. (2015). Osnovy hristianskoj jeshatologii [Fundamentals of Christian eschatology] Kyiv: Lira-K [in Ukrainian].

2. Martyshin, D. S. (2019). Social'no-filosofskij analiz hristianskoj jeshatologii v dialoge gosudarstvennogo upravlenija i teologii [Socio-philosophical analysis of Christian eschatology in the dialogue of public administration and theology]. Aspekti publichnogo upravlinnja [Aspects of public administration], 1-2, 61-69 [in Ukrainian].

3. Bochkov, P. V., Martyshin, D. S. (2015). Hristianskaja jeshatologija i social'naja praktika

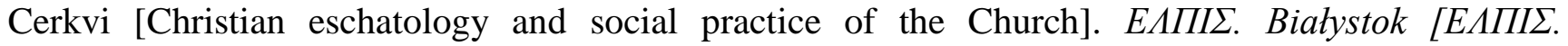
Białystok], 17, 139 - 144 [in Ukrainian].

4. Hodr, Georgij, mitropolit Gor Livanskih (2006). Prizyv Duha: Cerkov' i obshhestvo [The Call of the Spirit: The Church and Society] Kyiv: Duh i Litera [in Ukrainian].

5. Ilarion (Alfeev), mitropolit (2014). Konec vremen [The End of Times] Moscow: JeKSMO [in Russian].

6. Ioann (Ziziulas), mitropolit. (2006). Bytie kak obshhenie: Ocherki o lichnosti $i$ Cerkvi [Genesis as Communication: Essays on the Person and the Church ] Moscow: Svjato-Filaretovskij pravoslavno-hristianskij institut [in Russian].

7. Kashljuk, V. S. (2015). Hristianskaja jeshatologija v trudah predstavitelej russkoj religioznofilosofskoj mysli XX veka [Christian eschatology in the works of representatives of Russian religious and philosophical thought of the XX century] Kyiv: Lira-K [in Ukrainian].

8. Frank, S. L. (2003). S nami Bog [God is with us]. Moscow: AST [in Russian].

9. Frank, S. L. (1998) Svet vo t'me. Opyt hristianskoj jetiki i social'noj filosofii [in the dark. Experience of Christian ethics and social philosophy]. Moscow: Faktorial [in Russian].

10. Rajt, T. (2009). Glavnaja tajna Biblii: Smert' i zhizn' posle smerti v hristianstve [The main mystery of the Bible: Death and life after death in Christianity ]. Moscow: Jeksmo [in Russian]. 